\title{
Seyahat Acentelerinde Otantik Liderliğin Çalışanların Yalakalık Eğilimlerine Etkisi
}

\author{
The Effect of Authentic Leadership on Employees' Sycophancy Tendency in Travel Agencies
}

\author{
Özkan TÜTÜNCÜ*, YıImaz AKGÜNDÜZ** \\ **Prof. Dr., Dokuz Eylül Üniversitesi, Spor Bilimleri ve Teknolojisi Yüksekokulu, Rekreasyon Bölümü, Sağllk Kampusu, 35340, İnciraltı, İzmir \\ E posta: ozkan.tutuncu@deu.edu.tr \\ **Yrd. Doç. Dr., Mersin Üniversitesi, Turizm Fakültesi, Gastronomi ve Mutfak Sanatları Bölümü, Çiftlikköy Kampusu, 33343, Yenişehir, Mersin \\ E posta: yilmazakgunduz@mersin.edu.tr
}

MAKALE BILGILERI

Makale işlem bilgileri:

Gönderilme tarihi: 14 Eylül 2013

Birinci değerlendirme: 23 Ekim 2013

İkinci değerlendirme: 19 Aralı 2013

Kabul: 22 Aralık 2013

Anahtar sözcükler:

Otantik liderlik, Yalakalık, Seyahat acenteleri.

\section{ÖZ}

Etik liderlik kuramına bağlı olarak geliştirilen otantik liderlik; liderin umut, iyimserlik ve güven gibi pozitif psikolojik değerlere bağlı olarak izleyenlerini motive etmesine dayanmaktadır. Bu çalışmada yöneticilerin otantik liderlik davranışlarının, çalışanların yalakalık eğilimine etkisinin belirlenmesi amaçlanmaktadır. Bu amaçla Otantik Liderlik Envanterinden yararlanılarak bir anket oluşturulmuştur. Anket kolayda örnekleme yöntemi ile Kuşadası'nda bulunan seyahat acentesi çalıșanlarına yüz yüze ve bırak-topla anket toplama tekniği kullanılarak 2013 yılının Şubat ayında uygulanmıştır. Araştırmaya 126 seyahat acentesi çalışanı katılmıştır. Yapılan çoklu regresyon analizi sonucunda otantik liderliğin dengeli davranış ve bireysel farkındalık boyutlarının çalışanların yalakalık eğilimlerini negatif olarak etkilediği belirlenmiștir. Bu etkiye bağlı olarak seyahat acentesi yöneticilerine, çalıșanların güvenini kazanmaları ve yalakalık yapılarak daha başarılı olunamayacağı algısını yaratmaları için dengeli davranış ve bireysel farkındalık davranışlarını göstermeleri önerilebilir.

\section{ARTICLE INFO}

Article history:

Submitted: 14 September 2013

Resubmitted: 23 October 2013

Resubmitted: 19 December 2013

Accepted: 22 December 2013

Key words:

Authentic leadership, Sycophancy,

Travel agencies.

\begin{abstract}
Authentic leadership which is developed depending Ethical Leadership Theory, is based on motivating the followers by establishing psychological values such as hope, optimism and trust. This research seeks to find out the effect of managers' authentic leadership behaviors on employees' sycophancy tendency. For this purpose, Authentic Leadership Inventory was used in data collection. The study drew its data by convenience sampling method through face to face and ball-drop questionnaires applied to 126 employees of travel agencies in Kusadası, in February 2013. As a result of multiple regression analysis, it is revealed that the balanced processing and self-awareness that is, sub-dimensions of authentic leadership have negative effect on the perception of the employees about being more successful by buttering up to managers. The findings suggest to travel agency managers that by showing balanced processing and self-awareness behaviors to the employees, the perception of being more successful by buttering up could be prevented and employee trust could be gained as well.
\end{abstract}

\section{GiRiş}

Rekabetin artması ile birlikte işletmelerin başarılı olabilmeleri için yenilikçi, motivasyonu yüksek, değişime hızlı uyum sağlayabilen ve işine bağlı çalışanlara olan ihtiyaçları artmıştır. Ancak günümüzde çalışanların iş tatmin düzeyi oldukça düşük düzeyde kalmakta (Bayrak Kök 2006) ve çalışanlar daha iyi şartlarda yeni bir iş bulduklarında çalıştıkları örgütü değiştirmek istemektedirler (Abraham 1999; McNatt ve Judge 2008). Bu bağlamda yöne- ticilerin davranışları çalışanların iş tatminlerini, motivasyonlarını, işe ve örgüte yönelik tutumlarını etkilemektedir (Ogbonna ve Harris 2000; Scandura ve Williams 2004; Steyrer, Schiffinger ve Lang 2008; Tims, Bakker ve Xanthopoulou 2011; Wang, Tsui ve Xin 2011).

İnsan ilişkilerinin yoğun olarak yaşandığı sektörlerde bazı çalışanların kişisel kazanç sağlamak için etik dışı davranışlarda bulundukları görülmektedir (Murhpy, Smith ve Daley 1992; Wong 1998; Val- 
len ve Casado 2000; Yeung 2004). Gerek işgören-işgören gerekse işgören-yönetici arasında yaşanan ilişkilerde sergilenen en yaygın etik dışı davranışlar; ayrımcılık, kayırma, rüşvet, yıldırma, ihmal, sömürü, bencillik, yolsuzluk, işkence, yaranma (dalkavukluk-yalakalık), şiddet (baskı-saldırganlık), ilişkilere politika karıştırma, hakaret ve küfür, bedensel ve cinsel taciz, kötü alışkanlıklar, görev ve yetkinin kötüye kullanımı, dedikodu (söylenti), zimmet, dogmatik davranış ve yobazlıktır (Acar 2000:40-44; Aydın 2001:60-69).

Bu çalışmada yöneticilerin otantik liderlik davranışlarının çalışanların yalakalık eğilimine etkisinin belirlenmesi amaçlanmaktadır. Bu doğrultuda öncelikle otantik liderlik ve yalakalık konularının kuramsal çerçevesi oluşturulmaya çalışılmıştır. Çalışmanın araştırma kısmında, Kuşadası'nda bulunan seyahat acentelerinde çalışan işgörenlerden toplanan veriler analiz edilmiştir. Son olarak ise korelasyon ve regresyon analizleri yapılarak analiz sonuçları değerlendirilmiş ve önerilerde bulunulmuştur.

\section{KURAMSAL ÇERÇEVE}

\section{Otantik Liderlik}

Etik liderlik, izleyicilerin davranışlarını yönlendirmek için etik standartlar geliştiren, değerlerle etik standartları bütünleştiren ve bu etik standartları etkili şekilde uygulayan bir liderlik olarak kabul edilmektedir (Connock ve Johns 1995:2). Etik liderliğin bir türü olan otantik liderlik teorisi ise umut, iyimserlik, öznel iyi oluş ve duygusal zeka gibi pozitif duygulara odaklandığ 1 için pozitif örgütsel davranış içerisinde yer alan liderlik teorilerinden biri olarak kabul edilmektedir (Luthans 2002; Luthans vd. 2001; Yammarino vd. 2008). Otantik liderlikte esas olan güvenilir olma ve etiğe uygun davranmaktır (Turhan 2007).

Otantik liderin izleyenlerini etkilemede kullandığı temel unsur güvenilirliğidir. Otantik liderler karar ve eylemlerinde etik değerlere bağlı kalarak açık ve şeffaf davrandığı için izleyicileri tarafından güvenilir bir lider olarak kabul edilirler (Kernis 2003). Avolio, Bass ve Jung (1999:4) otantik lideri kendi düşüncelerinin, davranışlarının ve diğerleri tarafından nasıl algılandığının farkında olan; kendisinin ve diğerlerinin değerlerini, ahlaki bakış açlarını, bilgilerini ve güçlü yönlerini bilen; içinde bulunduğu ortamı tanıyan; kendisine güvenen; umudu olan, iyimser ve sorunların üstesinden çabuk gelebilen ahlaki birey olarak tanımlamıştır. Luthans ve Avolio (2003) ise otantik liderliği pozitif liderlik yetenekleri ve gelişmiş örgüt kavramının birleştiği bir süreç olarak ifade etmiştir. Avolio, Bass ve Jung (1999) ile Luthans ve Avolio'nun (2003) yaptığ 1 tanımlardan yola çıkarak otantik lideri; kendi güçlü ve zayıf yönlerinin farkında olan, düşündüklerini davranışlarına yansıtan, izleyenlerinin hassas olduğu konuları bilmesine rağmen doğruluktan ve içtenlikten ödün vermeyen, çevresindeki insanlara umut, iyimserlik ve güven vererek motive eden, sorunları önyargılarına göre değil doğru bilgilere dayandırarak çözen birey olarak tanımlamak mümkündür.

Otantik liderler güçlü ve zayıf yönlerinin farkındadırlar. Bu nedenle,yakın ilişkilerinde duygularını ve düşüncelerini paylaşmak için daha yüksek seviyede dürüstlük, açıklık ve isteklilik gösterirler (Gardner vd. 2005:358). Otantik liderlere dışsal baskılar değil, kendi ahlak standartları ve değerleri rehberlik eder. Başkalarını mutlu etmek, menfaat sağlamak veya cezadan kaçmak için istemedikleri davranışları göstermezler (Luthans ve Avolio 2003; May vd. 2003).

Otantik liderler; güven, umut, iyimserlik, esneklik özellikleriyle kendini geleceğe uyumlu hale getirmek için çaba gösterirler. Bu, otantik liderin kendi farkındalığını pozitif olarak etkiler (Ilies, Morgeson ve Nahrgang 2005:376). Otantik liderlik bireysel farkındalık, ilişkisel şeffaflık, içselleştirilmiş ahlaki bakış ve dengeli davranış özellikleri üzerine kurulmuştur. Bireysel farkındalık liderin güçlü ve zayıf yönlerinin, kişisel özelliklerinin, değerlerinin ve duygularının farkında olmasını ve bunlara güvenmesini; ilişkisel şeffaflık liderin gerçek duygu ve düşüncelerini açıkca ifade etmesini; dengeli davranış liderin bir karar vermeden önce inkâr, abartma ve saptırma olmadan ilgili bütün bilgileri tarafsız olarak analiz etmesini; içselleştirilmiş ahlaki bakış ise şeffaf bir karar alma sürecini içermektedir (Luthans ve Avolio 2003; Kernis 2003; May vd. 2003).

\section{Yalakalık}

TDK'nın yaptığı tanıma göre; yalaka kelimesi dalkavuk ve sırnaşık anlamına; yalakalık ise yalakalık etmek anlamına gelmektedir (Türk Dil Kurumu 2013). Yalakalık davranışının özünde kişilerin kendilerine veya başkalarına menfaat sağlamak için 
abartma, inkar ve gerçekleri saptırma gibi davranışlar göstermeleri vardır (Rosenthal ve Pittinsky 2006:622).

Yönetim sürecinde kararlarda, uygulamalarda, eylem ve işlemlerde kaçınılması gereken davranışlar arasında yer alan, mecazi anlamda dünyanın en eski mesleklerinden biri olarak kabul edilen yalakalık, kendisine çıkar sağlayacak olanlara karşı aşırı bir sayg1 ve hayranlık göstererek yaranma davranışı olarak da ifade edilmektedir (Aydın 2001:6069). Yönetim bilimi açısından bakıldığında yalakalığın püf noktası liderin duymak istediklerini söylemek veya dobra dobra konuşmaktan şiddetle kaçınmaktır (Burke, Trahant ve Koonce 1999:200).

Yalakalık her ne kadar toplumda kabul görmeyen bir davranış olarak ifade edilse de birçok kademede gereklilik olgusu haline gelmiştir (Lamberton ve Minor-Evans 1995:334). Çoğunlukla ast-üst ilişkilerinde gündeme gelen yaranma davranışının bir boyutu olarak değerlendirilebilecek yalakalık, aynı statüdeki çalışanların kişisel yarar sağlamak için yöneticilerine yalakalık yapmaları biçiminde ortaya çıkmakta ve çalışanların birbirinden tedirgin olmalarına da neden olabilmektedir (Gül 2006:70).

Çalışanlar davranışlarının doğrudan kendilerine bir yarar sağlayacağını algıladıklarında yöneticilerine saygılarını göstermek için abartılı davranışlarda bulunabilirler. Yalakalık davranışı gösteren çalışanlar örgütte kendi pozisyonlarını sağlamlaştırdıklarını düşündüklerinde ise daha düşük rütbe veya statüye sahip çalışanları azarlamakta veya suistimal etmektedirler. Bu çalışanlar, örgüt içerisinde iyi bir konuma sahip olsalar bile diğerlerinin saygısını kazanmaları oldukça zordur (Dalton 2008:360).

İlk kez Snyder (1974) tarafından bireylerin içlerinden gelmemesine rağmen sosyal yönden uygun sayılan ölçütleri fark edip buna göre davranışlarını şekillendirmesi olarak ifade edilen kendini gösterim (self-monitoring) davranışı ile yalakalık davranışının ilişkili olduğu söylenebilir. Düşük kendini gösterim özelliğine sahip çalışanlar, sosyal çevrelerinden dişlanmalarına neden olsa bile yaranmak için içlerinden gelmeyen davranışları göstermezken; yüksek kendini gösterim özelliğine sahip çalışanlar içlerinden gelmediği halde davranışlarını sosyal yönden uygun sayılan ölçütlere göre ayar- lamak için çaba gösterirler (Turnley ve Bolino 2001; Umay 1993).

\section{Otantik Liderlik ve Yalakalık iliş̧kisi}

Blau (1968) ve Homans'a (1958) göre sosyal değişim kuramının temel varsayımı, insanların ödüllendirilme beklentisi ile ilişkiye girmesi ve ilişkilerini sürdürmesidir (Ak.Lambe, Wittman ve Spekman 2001:4). Bu teoriye göre açıklanabilecek yalakalık, örgüt içerisinde çalışanların terfi ve daha fazla ücret artışı elde etmek için yöneticilerine hoş görünmek amacıyla gösterdikleri davranışlardır. Örgüt içerisindeki yönetsel uygulamalara bağlı olarak, çalışanların yalakalık davranışı göstermeleri kolaylaşmakta veya zorlaşmaktadır (Bingöl 2006:294). Ancak sosyal değişim kuramına göre çalışanların elde edeceği kazanımlar, yöneticilerinin takdirine bırakıldığı için (Gürbüz 2006) yalakalık davranışının kendisine menfaat sağlayacağına yönelik inancı düşük olan çalışanların, bu davranışı göstermek için daha az istekli olacakları söylenebilir.

Örgüt kültürü ve liderin davranışları, çalışanların yalakalık ile ilişkilendirilebilecek davranışlarını etkilemektedir (Bingöl 2006:294). Temel çıkış noktası lider ve izleyenler arasındaki karşılıklı güven ilişkisi olan otantik liderlik stilinde, menfaat sağlamak için çalışanların gösterdiği ahlaki olmayan davranışlar, yanlış bir uygulama olarak kabul edilir (Ilies, Morgeson ve Nahrgang 2005). Bu nedenle otantik liderin bulunduğu bir örgütte, çeşitli maddi ve sosyal kazanımlar elde etmek için çalışanların yalakalık davranışından uzak durması beklenebilir. Otantik liderler ödüllendirme ve cezalandırma sürecinde çalışanlarının performanslarını ve örgüt içerisindeki davranışlarını esas alırlar (Kernis 2003). Bu nedenle yalakalık davranışının kendisine menfaat sağlamayacağına inanan çalışanların, bu davranışı göstermeye daha az istekli olması beklenmektedir. Ayrıca otantik liderlerin yaptığı objektif ve adil değerlendirmeler, çalışanlarının liderlerine güvenmelerini sağlayacaktır. Nitekim yapılan çalışmalarda (Ilies, Morgeson ve Nahrgang 2005; Harter 2002; Harter, Schmidt ve Hayes 2002; May vd. 2003) liderin dengeli davranışının, ahlaki bakışının, bireysel farkındalığının ve ilişkisel şeffaflık özelliğinin, çalışanların yöneticilerine ve örgüte olan güvenlerini olumlu yönde etkilediği belirlenmiştir. Buradan hareketle otantik liderlik davranışlarının çalışanların 
yalakalık eğilimine olan etkisini belirlemek amacıyla, aşağıdaki hipotezler geliştirilmiştir:

H1:Dengeli davranışın, çalışanların amirlerine yalakalık yapma eğilimleri üzerinde negatif etkisi vardır.

H2: İçselleştirilmiş ahlaki bakışın, çalışanların amirlerine yalakalık yapma eğilimleri üzerinde negatif etkisi vardır.

H3: Bireysel farkındahı̆̆ın, çalışanların amirlerine yalakalık yapma eğilimleri üzerinde negatif etkisi vardır.

H4: İlişkisel şeffaflı̆̆ın, çalışanların amirlerine yalakalık yapma eğilimleri üzerinde negatif etkisi vardır.

\section{YÖNTEM}

\section{Araştırmanın Amacı ve Kapsamı}

Örgüt kültürünün ve yöneticilerin liderlik davranışlarının, çalışanların yalakalık davranışı gösterme eğilimleri üzerinde etkili olduğu kabul edilmektedir (Bingöl 2006:294). Bu araştırmada seyahat acentelerinde yöneticilerin otantik liderlik davranışlarının, çalışanların yalakalık eğilimine olan etkisinin belirlenmesi amaçlanmaktadır. Çalışmanın alan araştırması Kuşadası'nda bulunan seyahat acentelerinde yapılmıştır. Araştırmanın yapıldığı 2013 yılı Şubat ayında TURSAB (Türkiye Seyahat Acentaları Birliği 2013) kayıtlarına göre 111 adet A Sınıfı, iki adet B Sınıfı ve bir adet C Sınıfı olmak üzere toplam 114 adet seyahat acentesi bulunmaktadır. Araştırmanın yapıldığı dönemde aktif olarak faaliyetlerini sürdüren ve araştırmacılar tarafından ulaşılan 48 seyahat acentesinde çalışan 174 kişi çalışmanın evrenini oluşturmaktadır. Ana kütleden $\% 95$ güvenirlik sınırları içerisinde $\% 5$ lik hata payı dikkate alınarak örneklem büyüklüğü 120 kişi olarak hesaplanmıştır (Sekaran 2002). Araştırmada ankete cevap veren tüm çalışanlar örnekleme dahil edilmek istendiği için kolayda örnekleme yöntemi tercih edilmiştir. Alan araştırması sırasında acentede bulunan ve cevaplamayı kabul eden çalışanlara yüz yüze anket toplama yöntemi kullanılmakla birlikte acentede bulunmayan veya daha sonra anketi cevaplamak isteyen acente çalışanları için bırak-topla anket toplama yöntemi tercih edilmiştir. Araştırma dönemi sonunda toplanan 132 anketten ön kabul şartlarına sahip olmayan altı anket çıkarildıktan sonra kalan 126 anket geçerli olarak kabul edilmiştir.

\section{Veri Toplama Aracı}

Araştırmada veriler, alan yazına dayalı olarak geliştirilen bir anket ile toplanmıştır. Ankette bağımsız ve bağımlı değişkene yönelik ifadelerin yanı sıra, katılımciların demografik özelliklerini belirlemeye yönelik dört adet kapalı uçlu soru yer almaktadır. Anket formunda yöneticilerin liderlik davranışlarını belirlemek amacıyla Neider ve Schriesheim (2011) tarafından geliştirilen Otantik Liderlik Envanteri'nden (Authentic Leadership Inventory -ALI) yararlanılmıştır. Envanter; bireysel farkındalık (üç madde), ilişkisel şeffaflık (üç madde), içselleştirilmiş ahlaki bakış (dört madde) ve dengeli davranış (dört madde) boyutlarından oluşmaktadır. Envanterin ön-testi öğretim üyeleri ile gerçekleştirilerek, içerik geçerliliği sağlanmıştır.

Araştırma değişkenlerinin bir kurama dayandırılması veya günlük yaşantıdan esinlenerek belirlenmesi mümkündür (Knoke ve Bohrnstedt 1991). Ayrıca bağımlı değişkenlerin ölçülmesinde kompozit değişkenlerin yerine, tekli ve genel olarak başlayan ifadeler tercih edilebilir (Scarpello ve Campbell 1983). Bu araştırmanın bağımlı değişkeni olan yalakalık ile ilgili henüz bir ölçek geliştirilmemiştir. Belirtilen açıklamalara bağlı olarak, bu araştırmada hem günlük yaşantıdan esinlenerek hem de sosyal değişim teorisine dayandırılarak bir bağımlı değişken ifadesi anket formuna eklenmiştir. Söz konusu bağımlı değişken ifadesi "Genel olarak yağcılık ve yalakalık yapanlar, işte daha başarılı olurlar" olarak belirlenmiştir. Bağımlı ve bağımsız değişkenlere ait ifadelerin yanıt kategorileri "kesinlikle katılıyorum" ile başlayıp devam ederek Likert tipinde beşli olarak derecelendirilmiş ölçek ile ele alınmıştır.

\section{BULGULAR}

Araştırmaya Kuşadası'nda bulunan seyahat acentelerinde çalışan 126 kişi katılmıştır. Araştırmaya katılanların \%37'si (46 kişi) kadın, \%63'ü (80 kişi) erkektir. \%60'ı (76 kişi) evli olup, \%40' (40 kişi) bekârdır. \%19'u (23 kişi) ilköğretim, \%21'i lise ve dengi (26 kişi), \%60' 1 (77 kişi) üniversite mezunudur. \%21'inin (26 kişi) yaş aralığ 25 ve altı, \%56'sının (69 kişi) yaş aralığ 26 ile 35, \%27'sinin (29 kişi) yaş aralığı ise 36 ve üstüdür.

Demografik verilere ilişkin bulgulardan sonra otantik liderlik envanterinin yapısal geçerliliği ve 
içsel tutarlılığ test edilmiştir. Envanterin güvenirliğini test etmek amacıyla her bir boyuta yönelik güvenilirlik (Cronbach's Alpha) değerleri hesaplanmıştır. Yapısal geçerliliğini belirlemek amacıyla ise açılayıcı faktör analizi uygulanmıştır. Faktör sayısının tespitinde öz değerin 1'den büyük olmasına, maddenin ilgili faktör ile en az 0,300 düzeyinde yüke sahip olmasına (Hair, Money ve Samouel 2007:99-100), bir faktörün en az üç maddeden oluşmasına, binişik durumda olan iki faktör arasındaki yük farkının en az 0,100 olmasına (Tavşancıl 2002:50) ve Varimax dönüşümü uygulanmasına karar verilmiştir.

Otantik Liderlik Envanteri için faktör analizi sonucunda Kaiser-Meyer-Olkin örneklem değeri 0,725; Barlet Testi değeri 816,241 ve $p<0,05$ düzeyinde gerçekleşmiştir. Bu iki sonuç verinin faktör analizine uygunluğuna ve çok değişkenli normal dağılım gösterdiğine bir kanıt oluşturmaktadır (Çokluk, Şekercioğlu ve Büyüköztürk 2010:208).

Tablo 1'e göre, ilk faktör dört maddeden oluşmakta ve toplam varyansın $\% 20,9^{\prime}$ unu açıklamak- tadır. Bu faktörde liderin inanç ve davranışlarındaki tutarlılık (,885), karar verirken kendi öz değerlerine bağlı kalması (,867), baskılara direnmesi $(, 830)$ ve davranışlarına ahlaki değerlerinin rehberlik etmesi $(, 812)$ maddeleri bir araya gelmiştir. $\mathrm{Bu}$ nedenle faktöre "İçselleştirilmiş Ahlaki Bakış" adı verilmiştir.

İkinci faktör toplam varyansın \%18,8'ini açıklamaktadır. Dört maddeden oluşan ikinci faktörde liderin kendi değerlerine karşı fikirlerin açıklanmasını istemesi (,850), farklı bakış açılarını dikkate alması (,835), ilgili verileri tarafsız olarak araştırması $(, 796)$ ve karşıt görüşlerin dile getirilmesi için izleyenlerini cesaretlendirmesi (,857) maddeleri bir araya gelmiştir. Bu nedenle faktör “Dengeli Davranış" olarak adlandırılmıştır.

Ölçeğin üçüncü faktörü 3 maddeden oluşmakta ve varyansın $\% 16,9^{\prime}$ unu açıklamaktadır. Bireysel Farkındalık olarak adlandırılan bu faktörde liderin başkaları tarafından nasıl göründüğünün farkında olması $(, 891)$, kendi güçlü ve zayıf yönlerinin farkında olması $(, 876)$ ve başkalarının üzerindeki et-

Tablo 1. Otantik Liderlik Envanteri ile İlgili Açıklayıcı Faktör Analizi Sonuçları

\begin{tabular}{|c|c|c|c|}
\hline & $\begin{array}{r}\text { Faktör } \\
\text { Yükü }\end{array}$ & Öz değeri & $\begin{array}{r}\text { Varyansın } \\
\text { Açıklanma } \\
\text { Oranı }\end{array}$ \\
\hline İçselleştirilmiş Ahlaki Bakış & & 3,3437 & 20,964 \\
\hline Liderimin inandıkları ve davranışları arasında tutarlııı vardır. & ,885 & & \\
\hline Liderim karar verirken kendi öz değerlerini kullanır. & ,867 & & \\
\hline Liderim inandıklarının tersine davranması istendiğinde, baskılara direnir. & ,830 & & \\
\hline Liderimin davranışlarına sahip olduğu ahlaki değerler rehberlik eder. & ,812 & & \\
\hline Dengeli Davranış & & 2,784 & 18,812 \\
\hline Liderim kendi öz değerlerine karşı olan fikirlerin açıklanmasını ister. & ,850 & & \\
\hline Liderim bir karara varmadan önce farklı bakış açılarını dikkatle dinler. & ,835 & & \\
\hline Liderim karar vermeden önce ilgili verileri tarafsız olarak araştırır. & ,796 & & \\
\hline Liderim karşıt görüşlerini dile getirmesi için başkalarını cesaretlendirir. &, 717 & & \\
\hline Bireysel Farkındalık & & 2,221 & 16,893 \\
\hline Liderim kendi yeteneklerinin başkaları tarafından nasıl göründüğünün farkındadır. & ,891 & & \\
\hline Liderim kendi güçlü ve zayıf yönlerinin farkındadır. & ,876 & & \\
\hline Liderim başkaları üzerindeki etkisinin açıkça farkındadır. & ,857 & & \\
\hline İlişkisel Şeffaflık & & 1,806 & 16,531 \\
\hline Liderim söylemek istediklerini açıkça ifade eder. & ,888 & & \\
\hline Liderim bildiklerini açık bir şekilde başkalarıyla paylaşır. & ,869 & & \\
\hline Liderim düşüncelerini ve fikirlerini başkalarına açıkça ifade eder. & ,844 & & \\
\hline
\end{tabular}

Faktör Çıkarma Metodu: Temel Bileşenler Analizi; Döndürme metodu: Varimax

Kaiser-Meyer-Olkin Örneklem Yeterliliği : \%72,5 p<0,05

Barlett's Küresellik Testi için Ki-Kare: 816,241

Açıklanan toplam varyans: \%73,20; Ölçeğin tamamı için güvenirlik katsayısı: 0,850 
kisinin farkında olması $(, 857)$ maddeleri bir araya gelmiştir.

Ölçeğin son faktörü İlişkisel Şeffaflık olarak adlandırılmıştır. Üç maddeden oluşan faktör liderin söylemek istediklerini açıça ifade etmesi $(, 888)$, bildiklerini başkaları ile paylaşması (,869), düşüncelerini başkalarına açıkça ifade etmesi $(, 844)$ maddelerinden oluşmakta ve varyansın $\% 16,5^{\prime}$ ini açıklamaktadır.

Otantik liderlik davranışlarının kendi aralarındaki ilişkiyi belirlemek amacıyla korelasyon analizi yapılmıştır. Korelasyon analizi sonuçları, ortalamaları, standart sapmaları ve alpha değerleri Tablo 2'de görülmektedir.

Korelasyon tablosu incelendiğinde; otantik liderlik envanterinin tüm alt boyutları arasındaki ilişkinin anlamlı olduğu ve ilişkinin ,140 ile, 482 arasında değiştiği görülmektedir. Ayrıca envanterin alt boyutları arasında en yüksek ilişkinin bireysel farkındalık ile dengeli davranış boyutu arasında $(\mathrm{r}=, 482 \mathrm{p}<, 01)$, en düşük ilişkinin ise içselleştirilmiş ahlaki bakış ile ilişkisel şeffaflık arasında $(r=, 140$ $\mathrm{p}<, 05)$ olduğu da görülmektedir.

Yöneticilerin otantik liderlik davranışlarının, seyahat acentelerinde çalışanların yalakalık eğilimine etkisini belirlemek amacıyla çoklu regresyon analizi yapılmıştır. Bağımlı değişken (genel olarak yağcılık ve yalakalık yapanlar, işte daha başarılı olurlar) üzerinde birden fazla bağımsız değişkenin (dengeli davranış, ilişkisel şeffaflık, içselleştirilmiş ahlaki bakış ve bireysel farkındalık) toplu etkisini belirlemek için yapılan çoklu regresyon analizi Tablo 3'de yer almaktadır.
Tablo 3'te çalışanların yalakalık yapılarak daha başarılı olunacağına ilişkin algılarında yöneticilerinin gösterdiği içselleştirilmiş ahlaki bakış ve ilişkisel şeffaflık davranışının 0,05 anlamlılık düzeyinde anlamlı bir etkisinin olmadığ görülmektedir. Modelde dengeli davranış değişkenindeki bir birimlik artışın çalışanların yalakalık eğilimi üzerinde 0,309 birim; bireysel farkındalık değişkenindeki 1 birimlik artışın ise çalışanların yalakalık eğilimi üzerinde 0,262 birim azalışa neden olduğu görülmektedir. Bu sonuçlara bağlı olarak H1 ve H3 hipotezleri kabul edilirken, $\mathrm{H} 2$ ve $\mathrm{H} 4$ hipotezleri reddedilmiştir.

\section{SONUÇ VE ÖNERILER}

\section{Kuramsal Çıktılar}

Yapılan alanyazın incelemesinde yalakalık ile ilgili amprik bir çalışmaya rastlanılmamıştır. Bu nedenle kuramsal çıktılar bölümünde etik ve otantik liderlikle ilgili yapılan çalışmalardan örnekler verilmiştir. Acar ve Kaya (2012), yöneticilerin etik iklim oluşturduklarına dair çalışan görüşlerinin yaşa ve mesleki tecrübeye göre farklılaştı̆̆ını; Brown, Trevino ve Harrison (2005:120) etik liderliğin çalışanların etik karar vermeleri üzerinde etkili olduğu$\mathrm{nu}$; Costa ve McCrea (1992), Walumbwa ve Schaubroeck (2009:1278) sorumluluk, güvenilirlik ve doğruluğun, dürüstlüğün göstergesi olduğunu ve bu davranışların aynı zamanda etik liderlikle aralarında anlamlı bir ilişkinin olduğunu; Mayer vd. (2009; 2012) etik liderliğin örgüt içerisinde olması istenmeyen sapkın davranışların azalmasında etkili olduğunu; Walumbwa, Morrison ve Christensen (2012) etik liderliğin grup içindeki davranışların belirlenmesinde önemli bir etken olduğunu ortaya koymuşlardır.

Tablo 2. Otantik Liderlik ve Yalakalık Değişkenlerine İlişskin Korelasyon Matriksi

\begin{tabular}{lrrrr}
\hline Değişkenler & 1 & 2 & 3 \\
\hline Dengeli Davranış (1) & 1 & & \\
\hline Bireysel Farkındalık (2) & $0,482^{* *}$ & $0,161^{*}$ & $0,469^{* *}$ & 1 \\
\hline İçselleştirilmiş Ahlaki Bakış (3) & $0,287^{* *}$ & $0,166^{*}$ & $0,140^{*}$ & 1 \\
\hline Ilişkisel Şeffaflık (4) & 3,598 & 3,814 & 4,251 & 4,057 \\
\hline Ortalama & 1,025 & 0,982 & 1,183 & 0,873 \\
\hline Standart Hata & $0,839^{* *}$ & $0,874^{* *}$ & $0,773^{* *}$ & $0,870^{* *}$ \\
\hline Cronbach's Alpha & & & &
\end{tabular}


Özkan Tütüncü - Yılmaz Akgündüz

Tablo 3. Otantik Liderlik Davranışlarının Yalakalık Yapma Eğilimine Etkisini İnceleyen Regresyon Analizi

\begin{tabular}{lcrr}
\hline Bağımsız Değişkenler & $\beta$ & $t$ & Sig. \\
\hline (Sabit) & & 9,770 &, 000 \\
\hline Dengeli Davranış &,- 309 & $-2,945$ &, 004 \\
\hline Bireysel Farkındalık &,- 262 & $-2,241$ &, 027 \\
\hline İçselleştirilmiş Ahlaki Bakış &, 065 &, 628 &, 531 \\
\hline İlişkisel Şeffaflık &,- 061 &,- 759 &, 450 \\
\hline F & 9,471 & & \\
\hline$R$ &, 488 & & \\
\hline$R^{2}$ &, 238 & & \\
\hline
\end{tabular}

Otantik liderliğin çalışanların örgüte ve yöneticiye güvenleri (Gardner vd. 2005), iyimserlik, bağlılık ve iyimserlik duyguları (May vd. 2003) ve psikolojik iyi oluşları (Erickson 1995; Harter 2002; Harter, Schmidt ve Hayes 2002; Ilies, Morgeson ve Nahrgang 2005) üzerinde olumlu etkilerinin olduğu belirlenmiştir. Kuşadası'nda yapılan bu çalışmada dengeli davranış ve bireysel farkındalık boyutlarının, çalışanların yalakalık eğilimleri üzerinde negatif etkisinin olduğu belirlenmiştir. Ayrıca bu çalışmada yöneticilerin içselleştirilmiş ahlaki bakış ve ilişkisel şeffaflık özelliklerinin, çalışanların yalakalık eğilimleri üzerinde anlamlı bir etkisinin olmadığı da belirlenmiştir.

Otantik liderliğin yalakalık üzerinde olumsuz etkilerinin belirlendiği bu çalışmanın bulguları ile otantik liderliğin izleyenlerin güvenlerini artırd1ğını belirleyen çalışmaların bulgularının, benzeştiğini söylemek mümkündür. Otantik liderler kendi güçlü ve zayıf yönlerinin farkında olup, karar verme sürecinde adil davranmakta ve gerçek duyguları ile hareket etmektedirler. Bu kapsamda otantik liderlik stilinde, çalışanların kendilerine menfaat sağlamak için liderlerine hoş görünme, gereksiz iltifat etme veya gerçek görüşlerini belirtmeme gibi davranışlarda bulunmaları beklenemez.

\section{Uygulamaya Yönelik Çıktılar}

Bu çalışmada yöneticilerin göstermiş olduğu dengeli davranış ve bireysel farkındalık davranışlarının, çalışanların yalakalık eğilimlerini azaltıcı etkiye sahip olduğu belirlenmiştir. Bazı çalışanların yöneticilerine iltifat ederek veya itiraz etmeyerek, daha başarılı olunabileceği algısına sahip olmaları mümkündür. Çalışanlarının böyle bir algıya kapıl- malarını istemeyen yöneticiler, kendi güçlü/zayıf yönlerini dikkate alarak, bütün bilgileri tarafsız bir şekilde analiz etmelidirler.

Otantik liderliğin çalışanların yalakalık eğilimleri üzerindeki negatif etkisine bağlı olarak, yöneticilerin göstereceği dengeli davranış ve bireysel farkındalık davranışlarının, etik bir örgüt ikliminin oluşmasına katkı sağlayacağı da söylenebilir. Yöneticilerinin karar verme sürecinde konuyla ilgili tüm bilgileri objektif olarak değerlendirdiğine inanan çalışanlar, yöneticilerine ve dolayısıyla örgüte daha fazla güven duyabileceklerdir.

\section{Çalışmanın Sınırlılıkları}

Bu çalışma Kuşadası'nda faaliyet gösteren seyahat acentelerinde görev yapan çalışanlarla sınırland1rılmıştır. Çalışmanın konaklama, ulaştırma ve yiyecek-içecek işletmelerinde de uygulanması, farklı bölgelerle birlikte yapılması ve örneklem sayısının artırılması daha farklı ve sağlıklı yorumların yapılmasına yardımcı olabilecektir.

Çalışmada yararlanılan anket formunda otantik liderlik davranışlarını ölçmek amacıyla Neider ve Schriesheim (2011) tarafından geliştirilen Otantik Liderlik Envanteri'nden yararlanılmıştır. Bu alandaki diğer çalışmalarda otantik liderlik davranışını ölçmek için Avolio, Gardner ve Walumbwa (2007) tarafından geliştirilen Authentic Leadership Questionnaire-ALQ'dan yararlanılabilir. Ayrıca bundan sonraki çalışmalarda otantik liderlik ve yalakalık ile birlikte kişilik özellikleri ve örgütsel bağlılığa ilişkin ifadelere yer verilmesi; konaklama, ulaştırma ve yiyecek-içecek işletmelerinde de uygulanması daha farklı hipotezlerin sinanmasina ve yeni çıkarımlarda bulunulmasına katkıda bulunabilir. 


\section{KAYNAKÇA}

Abraham, R. (1999). The Relationship between Differential Inequity, Job Satisfaction, Intention to Turnover, and SelfEsteem, The Journal of Psychology: Interdisciplinary and Applied, 133(2): 205-215.

Acar, A. G. (2000). Etik Değerlerin Kurumsallaştırılması Üzerine Bir Araştırma (Yayımlanmamış Yüksek Lisans Tezi), İstanbul: İstanbul Üniversitesi Sosyal Bilimler Enstitüsü.

Acar, G. ve Kaya, M. (2012). Okul Yöneticilerinin Etik Liderlik Davranışlarına İliş̧kin Beden Eğitimi Öğretmenlerinin Görüşleri, Selçuk Üniversitesi Beden Eğitimi ve Spor Bilimleri Dergisi, 14(1): 95-102.

Avolio, B. J., Bass, B. M., ve Jung, D. I. (1999). Re-examining the Components of Transformational and Transactional Leadership Using the Multifactor Leadership Questionnaire, Journal of Occupational and Organizational Psychology, 72: 441-462.

Avolio, B., Luthans, F. ve Walumbwa, F.O. (2004). Authentic leadership: Theory-Building for Veritable Sustained Performance. Working Paper. Gallup Leadership Institute, University of Nebraska, Lincoln.

Avolio, B.J., Gardner, W.L. ve Walumbwa, F.O. (2007). Authentic Leadership Questionnaire.www.mindgarden.com, Erişim tarihi: 10 Aralık 2010.

Aydın, İ. P. (2001).Yönetsel, Mesleki ve Örgütsel Etik. 2. Bask1, İstanbul: Pegem Yayıncilik.

BayrakKök, S. (2006). İş Tatmini ve Örgütsel Bağlllığın İncelenmesine Yönelik Bir Araştırma, Atatürk Üniversitesi İktisadi ve İdari Bilimler Dergisi, 20(1): 291-310.

Blau, P. M. (1960). A Theory of Social Integration, The American Journal of Sociology, 65 (6): 545-556.

Bingöl, D. (2006). İnsan Kaynakları Yönetimi. 6. Baskı, İstanbul: Arıkan Basım Yayım.

Bolat, O. İ., Bolat, T. ve Aytemiz Seymen, O. (2009). Güçlendirici Lider Davranışları ve Örgütsel Vatandaşlık Davranışı Arasındaki İlişkinin Sosyal Mübadele Kuramından Hareketle İncelenmesi, BAÜ Sosyal Bilimler Enstitü Dergisi, 12(21): 215-239.

Brown, M. E., Treviño, L. K. ve Harrison, D. (2005). Ethical Leadership: A Social Learning Perspective for Construct Development and Testing, Organizational Behavior and $\mathrm{Hu}$ man Decision Processes, 97: 117-134.

Burke, W., Trahant, W. ve Koonce, R. (1999). Business ClimateShiftsProfiles of ChangeMakers. Boston, MA: Butterworth Heineman.

Çokluk, Ö., Şekercioğlu, G. ve Büyüköztürk, Ş. (2010). Sosyal Bilimler İçin Çok Değiş̧enli İstatistik SPSS ve Lisrel Uygulamaları. Ankara: Pegem Akademi.

Connock, S. ve Johns, T. (1995). Ethical Leadership. Londra: Institute of Personal Development.

Costa, P. T. ve McCrea, R. R. (1992). Four Ways Five Factors Are Basic, Personality and Individual Differences, 13: 653-665.

Dalton, C. M. (2008). In My Opinion, Business Horizons, 51: 351-361.

Erickson, R. J. (1995). Our Society, Our Selves: Becoming Authentic in an Inauthentic World, Advanced Development, 6: 27-39.

Gardner, W.L., Avolio, B.J., Luthans, F., May, D.R. ve Walumbwa, F. (2005). Can You SeeThe Real Me? Q A Self-Based Model of Authentic Leader and Follower Development, The Leadership Quarterly, 16: 343-372.
Gül, H. (2006). Etik Dışı Davranışlar ve Ussallaştırılması: Devlet Hastanelerinde Bir Uygulama, Karamanoğlu Mehmetbey Üniversitesi Sosyal ve Ekonomik Araştırmalar Dergisi, 9(10): 65-79.

Gupta, N., Conroy, S. A. ve Delery, J.E. (2012).The Many Faces of Pay Variation, Human Resource Management, 22: 100-115.

Gürbüz, S. (2006). Örgütsel Vatandaşlık Davranışı ile Duygusal Bağlılık Davranışı Arasındaki İlişkilerin Belirlenmesine Yönelik Bir Araştırma, Ekonomik ve Sosyal Araştırmalar Dergisi, 3(1): 48-75.

Hair, J. F. Jr., Money, A. H., Samouel, P. ve Page, M. (2007). Research Methods for Business. Chichester, England: John Wiley \& Sons Ltd.

Harter, J. K., Schmidt, F. L. ve Hayes, T. L. (2002). BusinessUnit Level Relationship between Employee Satisfaction, Employee Engagement, and Business Outcomes: A Meta-Analysis, Journal of Applied Psychology, 87(2): 268-279.

Harter, S. (2002). Authenticity. İçinde; C. R. Snyder, ve S. Lopez (Editörler) Handbook of Positive Psychology (ss. 382-394). Oxford: Oxford University Press.

Homans, G. C. (1958). Social Behavior as Exchange, American Journal of Sociology, 63 (May): 597-606.

Ilies, R., Morgeson, F.P., Nahrgang, J.D. (2005). Authentic Leadership and Eudaemonic Well-Being: Understanding Leader-Follower Outcomes, The Leadership Quarterly,16: 373-394.

Kernis, M. H. (2003). Toward a Conceptualization of Optimal Self-Esteem, Psychological Inquiry, 14: 1-26.

Knoke, D. ve Bohrnstedt, G.W. (1991). Basic Social Statistics. New York: F.E.Peacock Publishers.

Lambe, C.J., Wittmann, C.M. ve Spekman, R. E. (2001). Social Exchange Theory and Research on Business-to-Business Relational Exchange, Journal of Business-to-Business Marketing, 8(3): 1-36.

Lamberton, L., Minor-Evans, L. (1995). Human Relations: Strategies For Success. Chicago: Irwin Mirror Press.

Luthans, F. (2002). Positive Organizational Behavior: Developing and Managing Psychological Strengths, Academy of Management Executive, 16 (1): 57-72.

Luthans, F. ve Avolio, B. (2003). Authentic Leadership: A Positive Development Approach. İçinde Positive Organizational Scholarship:Foundation of A New Discipline, K.S. Cameron, J. E. Dutton ve R.E. Quinn (Editörler) (ss.241-261). San Francisco: Berrett-Koehler.

Luthans, F., Luthans, K. W., Hodgetts, R. M. ve Luthans, B. C. (2001). Positive Approach to Leadership (PAL): Implications for Today's Organizations, Journal of Leadership Studies, 8 (2): 3-20.

May, D. R., Chan, A. Y. L., Hodges, T. D. ve Avolio, B. J. (2003). Developing the Moral Component of Authentic Leadership, Organizational Dynamics, 32: 247-260.

Mayer, D. M., Aquino, K., Greenbaum, R. L. ve Kuenzi, M. (2012). Who Displays EthicalLeadership andWhyDoes it Matter: An Examination of Antecedents and Consequences of Ethical Leadership, Academy of Management Journal, 55: 151-171.

Mayer, D. M., Kuenzi, M., Greenbaum, R., Bardes, M. ve Salvador, R. (2009). How LowDoesEthicalLeadershipFlow? Test of a Trickle-Down Model, OrganizationalBehaviorand Human DecisionProcesses, 108: 1-13. 
McNatt, B. ve Judge, T.A. (2008). Self-efficacy Intervention, Job Attitudes, and Turnover: A Field Experiment with Employees in Role Transition, Human Relations, 61(6): 783-810.

Murphy, P. R., Smith, J. E. ve Daley, J. M. (1992). Executive Attitudes, Organizational Size and Ethical Issues: Perspectives on a Service Industry, Journal of Business Ethics, 11: 11-19.

Neider, L.L. ve Schriesheim, C.A. (2011). The Authentic Leadership Inventory (ALI):Development and Empirical Test, The Leadership Quarterly, 22: 1146-1164.

Ogbonna, E., ve Harris, L.C. (2000). Leadership Style, Organizational Culture and Performance: Empirical Evidence from UK Companies, International Journal of Human Resource Management, 11(4): 766-788.

Rosenthal, S.A. ve Pittinsky, T.L. (2006). Narcissistic Leadership, The Leadership Quarterly, 17: 617-633.

Scandura, T. A. ve Williams, E. A. (2004).Mentoring and Transformational Leadership: The Role of Supervisory Career Mentoring, Journal of Vocational Behavior, 65(3): 448-468.

Scarpello, V. ve Campbell, J.P. (1983). Job Satisfaction and The Fit Between Individual and Organizational Rewards, Journal of Occupational Psychology, 56:315-328.

Sekaran, U. (2002). Research Method for Business. Wiley, John ve Sons, Incorporated.

Snyder, M. (1974). Self-Monitoring of Expressive Behavior, Journal of Personality and Social Psychology, 30(4): 526-537.

Steyrer, J., Schiffinger, M., ve Lang, R. (2008). Organizational Commitment- A Missing Link Between Leadership Behavior and Organizational Performance?, Scandinavian Journal of Management, 24: 364-374.

Tavşancıl, E. (2002). Tutumlarm Ölçülmesi ve SPSS ile Veri Analizi. Ankara: Nobel Yayın Dağıtım Ltd. Şti.

Tims, M., Bakker, A. B. ve Xanthopoulou, D. (2011). Do Transformational Leaders Enhance Their Followers' Daily Work Engagement, The Leadership Quarterly, 22: 121-131.
Turhan, M. (2007). Genel ve Mesleki Lise Yöneticilerinin Etik Liderlik Davranışlarının Okullardaki Sosyal Adalet Üzerindeki Etkisi (Yayımlanmamış Doktora Tezi), Fırat Üniversitesi, Sosyal Bilimler Enstitüsü.

Turnley, W. H., ve Bolino, M. C. (2001). Achieving Desired Images Which Avoiding Undesired Images: Exploring the Role of Self-Monitoring in Impression Management, Journal of Applied Psychology, 86: 351-360.

Türk Dil Kurumu, http://wwww.tdk.gov.tr, Erişim tarihi: 10 Eylül 2013.

Türkiye Seyahat Acentaları Birliği, http://www.tursab.org.tr, Erişim tarihi: 1 Şubat 2013.

Umay, A. (1993). Matematik Problemleri Çözmede Bazı Kişilik Özelliklerinin Etkisi, Eğitim ve Bilim, 87: 60-66.

Vallen, G. ve Casado, M. (2000). Ethical Principles for the Hospitality Curriculum, Cornell Hotel and Restaurant Administrations Quarterly, Nisan: 44-51.

Walumbwa, F. O. ve Schaubroeck, J. (2009). Leader Personality Traits and Employee Voice Behavior: Mediating Roles of Ethical Leadership and Work Group Psychological Safety, Journal of Applied Psychology, 94(5): 1275-1286.

Walumbwa, F.O., Morrison, E.W. ve Christensen, A.L. (2012). The Effect of Ethical Leadership on Group Performance: The Mediating Role of Group Conscientiousness and Group Voice, Leadership Quarterly, 23: 953-964.

Wang, H., Tsui, A. S. ve Xin, K.R. (2011). CEO Leadership Behaviors, Organizational Performance, and Employees' Attitudes, The Leadership Quarterly, 22: 92-105.

Wong, S.C.K. (1998). StaffJob-Related Ethics of Hotel Employees in Hong Kong, International Journal of ContemporaryHospitality Management, 10(3): 107-115.

Yammarino, F.J., Dionne, S.D., Schriesheim, C.A. ve Dansereau, F. (2008). Authentic Leadership and Positive Organizational Behavior: A Meso, Multi-Level Perspective, The Leadership Quarterly, 19: 693-707.

Yeung, S. (2004). Hospitality Ethics Curriculum: An Industry Perspective, International Journal of ContemporaryHospitality Management, 16(4): 253-262. 